PEREIRA, NS; ALVES JÚNIOR, AR; CELEDÔNIO, WF; RODRIGUES, EA; CHAVES, SWP; MEDEIROS, JF. 2018. Phosphate fertilization influences macronutrient accumulation in watermelon cv Magnum. Horticultura Brasileira 36: 346-352. DOI - http://dx.doi.org/10.1590/S0102-053620180310

\title{
Phosphate fertilization influences macronutrient accumulation in watermelon cv Magnum
}

\author{
Natanael S Pereira'; ${ }^{1}$ Antônio Roberto Alves Júnior²; Wilma F Celedônioº ${ }^{2}$ Esiana A Rodrigues ${ }^{1}$; Sérgio WP Chaves²; \\ José Francismar Medeiros ${ }^{2}$
}

${ }^{1}$ Instituto Federal de Educação, Ciência e Tecnologia do Ceará(IFCE), Limoeiro do Norte-CE, Brazil; natanaelsan@gmail.com; natanaelsan@ hotmail.com; esianarodrigues@hotmail.com; 르iversidade Federal Rural do Semi-Árido (UFERSA), Mossoró-RN, Brazil; roberto_87 jr@ hotmail.com; wilmaceledonio@hotmail.com; swchaves@ufersa.edu.br; jfmedeir@ufersa.edu.br

\begin{abstract}
Studies on nutrient uptake are important to understand nutritional needs of crops, which demand may also be influenced by fertilization management, particularly P fertilization. Thus, the aim of this study was to evaluate macronutrient accumulation and distribution in watermelon cv. Magnum, under two forms of phosphate fertilization. The experiment was carried out in a sandy-textured Argisol in Mossoró-RN. The experimental design was a randomized block design, arranged in split plot in time, with four replicates. We evaluated dose of $137 \mathrm{~kg} \mathrm{ha}^{-1}$ of $\mathrm{P}_{2} \mathrm{O}_{5}$ under two forms of fertilization [pre-planting (F0) and pre-planting + topdressing (F1)]. Triple superphosphate (SFT) was used for pre-planting applications and topdressing applications were done through fertigation using monoammonium phosphate (MAP, $34 \mathrm{~kg} \mathrm{ha}^{-1}$ of $\mathrm{P}_{2} \mathrm{O}_{5}$ ). Shoot samples $($ stem + leaf + fruit) of the experimental plots were collected at 27, 34,40 and 55 days after emergence (DAE), and quantitative values of the accumulated nutrients were determined. In general, the highest accumulation of macronutrients occurred in the last third of the crop cycle. General accumulation of macronutrient was altered by fertilization form. An increase in $\mathrm{P}$ accumulation was observed using F1 fertilization, both in total and in fruits. Macronutrient accumulation rates increased during the evaluation period, except for $\mathrm{Ca}$ and $\mathrm{Mg}$ in F1 fertilization. F1 fertilization provided higher total accumulations of $\mathrm{Ca}$ and $\mathrm{Mg}$, but the same did not occur for the accumulation in fruits.
\end{abstract}

Keywords: Citrullus lanatus, nutrient accumulation, phosphorus.

\section{RESUMO}

Formas de adubação fosfatada influenciam o acúmulo de macronutrientes pela melancieira 'Magnum'

Estudos de marcha de absorção de nutrientes são importantes para a definição das necessidades nutricionais das culturas, cuja demanda pode também ser influenciada pelo manejo da adubação, particularmente no caso do P. Assim, objetivou-se com este trabalho avaliar a marcha de acúmulo de macronutrientes da melancieira cv. Magnum irrigada submetida a duas formas de adubação fosfatada. $\mathrm{O}$ experimento foi realizado em Argissolo de textura arenosa, em Mossoró-RN, no delineamento experimental de blocos casualizados com parcelas subdivididas no tempo, com quatro repetições. Foi avaliada a dose de $137 \mathrm{~kg} \mathrm{ha}^{-1}$ de $\mathrm{P}_{2} \mathrm{O}_{5}$ sob duas formas de adubação [em pré-plantio (F0) e em pré-plantio + cobertura (F1)]. Superfosfato triplo (SFT) foi utilizado para as aplicações em pré-plantio e, as aplicações em cobertura foram feitas através de fertirrigação, utilizando fosfato monoamônico (MAP, $34 \mathrm{~kg} \mathrm{ha}^{-1} \mathrm{de}_{\mathrm{P}_{2}} \mathrm{O}_{5}$ ). Foram realizadas coletas aos $27,34,40$ e 55 dias após a emergência (DAE) da parte aérea total (caule + folha + fruto) das parcelas experimentais, determinando-se os quantitativos dos nutrientes acumulados. De forma geral, os maiores acúmulos de macronutrientes ocorreram no último terço do ciclo da cultura. A ordem geral de acúmulo de macronutrientes foi alterada com a forma de adubação, havendo aumento do acúmulo de P com a adubação F1, tanto no total como nos frutos. A variação das taxas de acúmulo de macronutrientes é crescente no período de avaliação, exceto para $\mathrm{Ca}$ e $\mathrm{Mg}$ na adubação $\mathrm{F} 1$. A adubação $\mathrm{F} 1$ proporcionou maiores acúmulos totais de $\mathrm{Ca}$ e $\mathrm{Mg}$, porém o mesmo não ocorre para o acúmulo nos frutos.

Palavras-chave: Citrullus lanatus, acúmulo de nutrientes, fósforo.

\section{Received on April 7, 2017; accepted on April 26, 2018}

$\mathrm{C}$ limatic conditions in Brazilian Northeast region are ideal to make watermelon a social and economic important crop. However, little information on nutritional needs of this crop may lead to an inefficient fertilization practice.

Phosphorus $(\mathrm{P})$ stands out among the important elements for vegetative growth and fruit development. Despite the fact that watermelon extracts low quantities of this element, when compared to nitrogen $(\mathrm{N})$ and potassium $(\mathrm{K})$, great quantities are used in fertilizations due to its low natural availability and/ or P-fixation capacity of soils, making it the main cause for low recovery efficiency of this element by most crops (Araújo \& Machado, 2006).

Due to the mentioned above, in conventional fertilization, $\mathrm{P}$ is applied in pre-planting, aiming to minimize its reaction with soil components. Nevertheless, some studies suggested 
that under determined conditions, phosphorus topdressing (via fertigation) may provide an increase in the efficiency of its use by crops (Marouelli et al., 2015).

Marouelli et al. (2015) state that $\mathrm{P}$ applied at pre-planting associated to fertigation can be a good strategy to ensure initial availability for plant development, as well as to keep appropriate levels for absorption of the element by plants throughout cultivation cycle.

Studying nutrient uptake of watermelon plant, Gonçalves et al. (2016) pointed out that recommendation for fertilization depends on each nutrient need for the crop, but also fertilization management and weather conditions in the cultivation region.

Studies on nutrient uptake under some management conditions provide information on nutritional needs, allowing adjustment of fertilizer rates and their higher efficiency.

Thus, the aim of this study was to evaluate nutrient accumulation and macronutrient partitioning by watermelon cv. Magnum irrigated under phosphate fertilization.

\section{MATERIAL AND METHODS}

The experiment was carried out at the Experimental Farm of UFERSA, municipality of Mossoró-RN, located in Alagoinha ( $5^{\circ} 3^{\prime} 30^{\prime \prime} \mathrm{S} ; 37^{\circ} 24^{\prime \prime} \mathrm{W}, 72$ $\mathrm{m}$ altitude), from November, 2014 to January, 2015. The climate of the region is hot and dry, BSwh type, according to Köppen.

Soil fertility evaluation was done following the methodology recommended by Embrapa (2009), showing the initial characteristics: $\mathrm{pH}$ $\left(\mathrm{H}_{2} \mathrm{O}\right)=5.7$; organic matter $\left(\right.$ in $\left.\mathrm{g} \mathrm{kg}^{-1}\right)=$ 18.43; P Mehlich (in $\mathrm{mg} \mathrm{dm}^{-3}$ ) $=4$; $\mathrm{K}^{+}$, $\mathrm{Na}^{+}, \mathrm{Ca}^{2+}, \mathrm{Mg}^{2+}, \mathrm{Al}^{3+}, \mathrm{H}+\mathrm{Al}^{3+}$ (in mmol $\left.\mathrm{dm}^{-3}\right)$ and $\mathrm{V}(\%)=2.30 ; 4.40 ; 14.7$; $5.0 ; 0.0 ; 24.8$; and 52 , respectively. The authors also determined clay fraction by pipette method $\left(80 \mathrm{~g} \mathrm{~kg}^{-1}\right)$ sand fractions $\left(905 \mathrm{~g} \mathrm{~kg}^{-1}\right)$ and silt $\left(1.5 \mathrm{~g} \mathrm{~kg}^{-1}\right)$ by sieving and by mass difference, respectively.

After soil preparation, which consisted of plowing and harrowing, the authors built ridges $(30 \mathrm{~cm}$ height $\mathrm{x} 60$ $\mathrm{cm}$ width). Soil was previously plowed and harrowed, building seedbeds $(20 \mathrm{~cm}$ height x $60 \mathrm{~cm}$ width).

Watermelon cv. Magnum was planted direct in the field, spaced 0.60 $\mathrm{m}$ between plants and $2.0 \mathrm{~m}$ between lines, on November 11, 2014. The authors adopted dripping fertilization system; Emitters were spaced $30 \mathrm{~cm}$, using an emitter flow rate of $1.13 \mathrm{~L} \mathrm{~h}^{-1}$ (under $64 \mathrm{kPa}$ pressure), and emission uniformity coefficient of $91 \%$. Irrigation was performed through monitoring soil moisture measuring the surface tension, keeping soil water matric potential greater than $-20 \mathrm{kPa}$.

Pre-planting phosphate fertilization was manual in $10-\mathrm{cm}$ depth pits, each $30 \mathrm{~cm}$ and next to each emitter $(10$ $\mathrm{cm})$. Topdressing applications were via fertigation using a shunt tank, connected to irrigation nets. Sources of P, used during pre-planting and topdressing (fertigation), were triple superphosphate (41\% P2O5) and monoammonium phosphate (61\% P2O5), respectively.

Sources of $\mathrm{N}$ (urea and ammonium sulfate), $\mathrm{K}$ (potassium chloride and potassium sulphate), $\mathrm{Ca}$ (calcium nitrate) and $\mathrm{Mg}$ (magnesium sulfate) were applied as topdressing via fertigation, from the first week after planting, totalizing 141, 148, 33, 7 and $28 \mathrm{~kg} \mathrm{ha}^{-1}$ of $\mathrm{N}, \mathrm{K}_{2} \mathrm{O}, \mathrm{CaO}, \mathrm{MgO}$ and $\mathrm{S}$, respectively.

The experimental design was of randomized blocks, factorial scheme, subdivided into four evaluation periods, with four replications. Experimental plots consisted of $24 \mathrm{~m}^{2}(12.0 \times 2.0 \mathrm{~m})$, being the useful plot of $9.60 \mathrm{~m}^{2}(4.8 \mathrm{x}$ $2.0 \mathrm{~m}$ ), with eight plants.

Two fertilization systems were evaluated [pre-planting (F0) and preplanting + topdressing (F1)]. All plots received a total dose of $137 \mathrm{~kg} \mathrm{ha}^{-1}$ of $\mathrm{P}_{2} \mathrm{O}_{5}$, considering that in $\mathrm{F} 1$ fertilization, part was applied as topdressing via fertigation, using monoammonium phosphate (MAP). For pre-planting applications, the authors used triple superphosphate (SFT).

Data were collected at 27,34, 40 and 55 days after emergence (DAE) from total shoot area (stem + leaf + fruit) of experimental plots. Plants were removed from field and put into plastic bags, taken immediately to Laboratório de Irrigação e Salinidade from Departamento de Ciências Ambientais of UFERSA, in order to be separated into stem, leaves and fruits. Then, these parts were weighed and taken into forced air circulation at $65^{\circ} \mathrm{C}$, being weighed again after drying.

Then, samples were ground (Willey type mill), for chemical analysis, according to Malavolta et al. (1997), in order to determine total $\mathrm{N}$, using semimicro Kjeldahl method, K, using flame emission photometry, $\mathrm{Ca}$ and $\mathrm{Mg}$, using atomic absorption spectrophotometry, $\mathrm{S}$, using turbidimetry and $\mathrm{P}$ through reduction of phosphor-molybdic complex.

Nutrient accumulations were obtained using the product between dry biomass and its concentration in the material.

Nutrient accumulation data $(\mathrm{g}$ plant $^{-1}$ ) were submitted to $\mathrm{F}$ test, at $5 \%$ significance, using computer statistical software SISVAR 5.3 (Ferreira, 2010), then submitted to regresssion analysis, using software Table Curve 2D (Scientific, 1991).

The significance of models was verified based on F-test probability and the model coefficients using $t$ test, with $*$ and $* *$ showing significance at $5 \%$ and $1 \%$, respectively. The models were selected considering their significance and coefficients and among those, the ones with the highest $\mathrm{R}^{2}$ value offered a simpler and more coherent explanation.

Rates of daily macronutrient accumulation were obtained through derivation of the models used.

\section{RESULTS AND DISCUSSION}

\section{Total accumulation}

A significant effect of macronutrient accumulation in relation to time was observed; considering that, for $\mathrm{Ca}$ and $\mathrm{Mg}$, shape X DAE interaction was also significant.

Overall, higher nutrient accumulations occurred in the last third of the cycle (Figure 1).

About $50 \%$ of total $\mathrm{N}, \mathrm{P}, \mathrm{K}$ and 
S were accumulated at $41,42,44$ and $42 \mathrm{DAE}$, respectively (Figure 1 ), which may be related to the fast plant development in experimental conditions, coinciding with the period in which fruits had already reached approximately $50 \%$ of their final dry biomass (45 DAE) (data not shown).

Climatic conditions which were favorable to shorten cycle allowed fast nutrient accumulation to meet fruit development demand, which began from the first collect (27 DAE), representing an important drain.

Studies on cv. Quetzale, in Mossoró, Lucena et al. (2011) verified higher increase of macronutrient accumulation after plant fructification. High nutrient requirement for the crop after fructification is corroborated in other studies, according to Gonçalves et al. (2016).

Maximum $\mathrm{N}$ accumulation was $12.64 \mathrm{~g}$ plant $^{-1}$ or $105 \mathrm{~kg} \mathrm{ha}^{-1}$ (8.333 plants ha ${ }^{-1}$ ), with increasing accumulation rates and ranging from 0.16 to $0.64 \mathrm{~g} \mathrm{day}^{-1}$ (Figure $1 \mathrm{~A}$ ).

Vidigal et al. (2009) verified a similar total $\mathrm{N}$ accumulation $(105.8$ $\left.\mathrm{kg} \mathrm{ha}^{-1}\right)$ for $\mathrm{cv}$. Crimson Sweet $(5,000$ plants $\mathrm{ha}^{-1}$ ); however, with a superior accumulation per plant (21.16 $\left.\mathrm{g} \mathrm{plant}^{-1}\right)$. Grangeiro \& Cecílio Filho (2004a) verified a total of $\mathrm{N}$ equivalent to 70.79 g plant ${ }^{-1}$ or $138.8 \mathrm{~kg} \mathrm{ha}^{-1}$ (1,960 plants $\left.\mathrm{ha}^{-1}\right)$ for watermelon Tide hybrid.

Despite the greater variability of accumulation per plant in literature, these represent better nutritional demand in relation to their production, as verified by Paula et al. (2011), relating extraction of $\mathrm{N}, \mathrm{P}$ and $\mathrm{K}$ by the crop with respective total productivity and productivity per plant, according to data found in literature.

In relation to $\mathrm{P}$, significant effect isolated both for DAE (Figure 1B) and for fertilization system was verified, considering that average accumulation of $\mathrm{P}$ in $\mathrm{F} 1$ fertilization $\left(0.96 \mathrm{~g} \mathrm{plant}^{-1}\right)$ was superior than in F0 fertilization $\left(0.67 \mathrm{~g} \mathrm{plant}^{-1}\right)$, approximately $43 \%$ or $0.29 \mathrm{~g}$.

F1 fertilization may have provided an increase in P availability in soil due to the effect of phosphate applied to fertigation. Simulating P uptake by roots in relation to the effect of fertilization, Wang \& Chu (2015) concluded that $\mathrm{P}$ in liquid form reduced fixation and increased $\mathrm{P}$ availability in soil.

Studying tomato crop, Marouelli et al. (2015) verified that $\mathrm{P}$ fertigation was more efficient than $P$ availability at pre-planting. According to Fernandes \& Soratto (2012) and Marouelli et al. (2015), it is important to highlight that an increase in P uptake is not necessarily related to an increase in crop production.

$P$ accumulation rates are increasing, ranging from 0.03 to $0.05 \mathrm{~g} \mathrm{day}^{-1}$ from 27 to $42 \mathrm{DAE}$ and reaching maximum value at $55 \mathrm{DAE}, 0.08 \mathrm{~g} \mathrm{day}^{-1}$ (Figure 1B).

Considering the model presented in Figure $1 \mathrm{~B}$ and average difference of $P$ accumulation $(0.29 \mathrm{~g})$ comparing fertilization systems, the authors estimated maximum accumulation of 1.56 and $1.85 \mathrm{~g} \mathrm{plant}^{-1}$ for F0 and F1 fertilizations, respectively, which correspond to estimates of 13 and 15.4 $\mathrm{kg} \mathrm{ha}^{-1}$ of P.

Grangeiro \& Cecílio Filho (2004a) reported similar $\mathrm{P}$ extraction for Tide hybrid (13.5 $\mathrm{kg} \mathrm{ha}^{-1}$ ) despite using a much lower planting density (1960 plants ha ${ }^{-1}$ ).

In relation to $\mathrm{P}$, cultivation conditions, including soil and fertilization management, may show greater effect on this element uptake by plants than planting density. Due to its relative immobility in soil, competition for $\mathrm{P}$ between plants is minimal (Novais \& Mello et al., 2007).

Vidigal et al. (2009) obtained total extraction equivalent to $18.1 \mathrm{~kg} \mathrm{ha}^{-1}$ of $\mathrm{P}\left(5,000\right.$ plants $\left.\mathrm{ha}^{-1}\right)$ for cv. Crimson Sweet, using a dose of about $300 \mathrm{~kg}$ ha $^{-1}$ of $\mathrm{P}_{2} \mathrm{O}_{5}$ in sandy soil with high $\mathrm{P}$ content, though.

Silva et al. (2012) reported total accumulations of only 8.12 and $8.80 \mathrm{~kg}$ $\mathrm{ha}^{-1}$ for cultivars Olímpia $(5,144$ plants $\mathrm{ha}^{-1}$ ) and Leopard (7,716 plants $\left.\mathrm{ha}^{-1}\right)$, adopting a dose of $220 \mathrm{~kg} \mathrm{ha}^{-1}$ of $\mathrm{P}_{2} \mathrm{O}_{5}$ in an Eutrophic Cambisol.

Phosphorus demand is also dependent on expectation for productivity (Paula et al., 2011). Estimates of nutrient accumulation, as well as average fresh weight per plant (6.98 $\mathrm{kg}$ with $4.47 \%$ fresh mass) obtained in this experiment can be a reference for this kind of study.

$\mathrm{K}$ is the most accumulated nutrient in plant, estimating a total of $18.03 \mathrm{~g}$ plant $^{-1}$ at $55 \mathrm{DAE}$, being equivalent to $150 \mathrm{~kg} \mathrm{ha}^{-1}$ of $\mathrm{K}$ or $181 \mathrm{~kg} \mathrm{ha}^{-1}$ of $\mathrm{K}_{2} \mathrm{O}$. Grangeiro \& Cecílio Filho (2004a) noticed similar maximum accumulation for Tide hybrid (155.5 $\mathrm{kg} \mathrm{ha}^{-1}$ of K). Other studies show lower accumulations, approximately $121 \mathrm{~kg}$ $\mathrm{ha}^{-1}$ for both cv. Crimson Sweet (Vidigal et al., 2009) and for cv. Olímpia (Silva et al., 2012).

The authors verified little range in total concentration of $\mathrm{K}$ from 27 to 55 DAE (between 42.51 and $38.17 \mathrm{~g}$ $\mathrm{kg}^{-1}$ ) (data not shown), pointing out a close relationship between biomass production and uptake of this nutrient.

This fact can be related to $\mathrm{K}$ role in transporting photosynthesis from source to drain (Marschner, 2012), being particularly important after fructification, when an intense translocation to fruits is noticed (Grangeiro \& Cecílio Filho, 2004b).

The rate of $\mathrm{S}$ accumulation is increasing, reaching $0.05 \mathrm{~g} \mathrm{day}^{-1}$ at 55 DAE, when a maximum accumulation, $0.90 \mathrm{~g} \mathrm{plant}^{-1}\left(7.50 \mathrm{~kg} \mathrm{ha}^{-1}\right)$, could also be verified.

Vidigal et al. (2009) verified maximum accumulation and uptake rate for $\mathrm{S}$ of $1.26 \mathrm{~g} \mathrm{plant}^{-1}(6.30 \mathrm{~kg}$ $\mathrm{ha}^{-1}$ ) and $0.06 \mathrm{~g} \mathrm{day}^{-1}$, respectively, for cv. Crimson Sweet in sandy soil in the Northern region of Minas Gerais State.

Grangeiro \& Cecílio Filho (2004a) showed superior $\mathrm{S}$ accumulations both in area $\left(9.1 \mathrm{~kg} \mathrm{ha}^{-1}\right)$ and per plant $(4.64 \mathrm{~g}$ plant $\left.{ }^{-1}\right)$, studying Tide hybrid in spacing $3.0 \times 1.7 \mathrm{~m}$ in a yellow red Argisol.

For $\mathrm{Ca}$ and $\mathrm{Mg}$, the authors verified that about $50 \%$ of these totals are accumulated at 40 and 42 DAE in F0 fertilization (Figure 2A), whereas for F1 fertilization, this accumulation occurs at 35 and $37 \mathrm{DAE}$. This behavior is due to the higher initial uptake rates of plants under F1 fertilization, although being decreasing (Figure 2B).

In $\mathrm{F} 1$ fertilization, maximum accumulations both for $\mathrm{Ca}(8.71 \mathrm{~g}$ plant $\left.^{-1}\right)$, and for $\mathrm{Mg}\left(2.64 \mathrm{~g} \mathrm{plant}^{-1}\right)$ are 
higher than in F0 fertilization, $6.27 \mathrm{~g}$ plant $^{-1}$ of $\mathrm{Ca}$ and $1.82 \mathrm{~g} \mathrm{plant}^{-1}$ of $\mathrm{Mg}$ (Figure 2).

Taking into consideration that transport of $\mathrm{Ca}$ and $\mathrm{Mg}$ to the roots is mainly via mass flow (Vitti et al., 2006; Marschner, 2012), plant transpiration, as well as nutrient concentration in soil solution shows direct relation to its uptake.

Chien et al. (2011) mention that some researchers have been stating about the acidifying effect of MAP ammonium nitrification and its uptake by the roots, which may increase the dissolution of precipitated $\mathrm{Ca}-\mathrm{P}$ compounds. Thus, MAP in F1 fertilization may have favored dissolution of $\mathrm{Ca}$ and $\mathrm{Mg}$, both soil and SFT (12\% CaO).

A more uniform $\mathrm{P}$ availability in soil in F1 fertilization may also have led to a better distribution of absorbent roots, making better water catchment and nutrient uptake. Changes in distribution and/or root activity may occur depending on phosphate fertilization system (Pan et al., 2011) or the combination of nutrients, such as $\mathrm{N}$ and $\mathrm{P}$, in fertilizers (Marschner, 2012).

Studying seedlings grafted on different coffee genotypes, Tomaz et al. (2003) attributed the increase of Ca content, in some treatments, to an increase of root system.

The general order of macronutrient accumulation in the plant in F0 fertilization $(\mathrm{K}>\mathrm{N}>\mathrm{Ca}>\mathrm{Mg}>\mathrm{P}>\mathrm{S})$ is similar to the one verified by Vidigal et al. (2009) working with cv. Crimson Sweet in sandy soil and Grangeiro \& Cecílio Filho (2004a) studying Tide hybrid in medium-texture soil.

In F1 fertilization, the concentration order was: $\mathrm{K}>\mathrm{N}>\mathrm{Ca}>\mathrm{P}>\mathrm{Mg}>\mathrm{S}$, showing an increase in $\mathrm{P}$ proportion in total composition of the nutrients.
Silva et al. (2012) also verified a greater $\mathrm{P}$ proportion in relation to $\mathrm{Mg}$ working with cv. Olímpia, in which the phosphate foundation fertilization was complemented with applications via fertigation.

\section{Fruit accumulation}

For fruit accumulation, the authors did not verify any significant interaction (shape X DAE). Maximum $\mathrm{N}$ accumulation estimated in fruits was 7.48 g plant $^{-1}$ (Figure 3A), which corresponds to, approximately, $59.1 \%$ of the total plant accumulation.

Other studies present proportions of $\mathrm{N}$ exports relatively close, $54 \%$ for $\mathrm{cv}$. Olímpia (Silva et al., 2012) and 63\% for cv. Crimson Sweet (Vidigal et al., 2009).

Grangeiro \& Cecílio Filho (2004a) pointed out the participation of $\mathrm{N}$ in fruits corresponding to $77 \%$ of the total accumulated by Tide hybrid; nevertheless, a reduction of $\mathrm{N}$ in

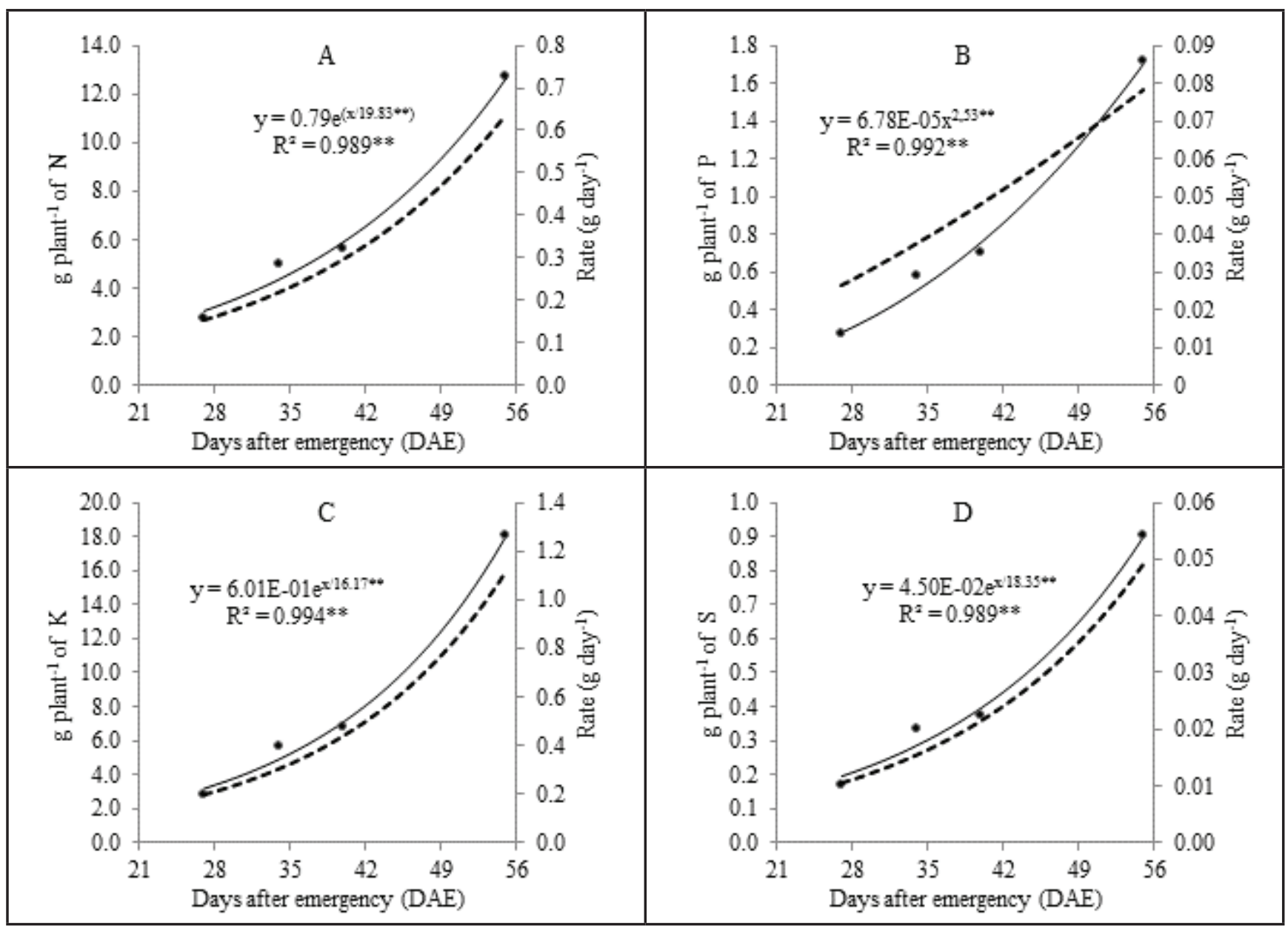

Figure 1. Total accumulations of $N(A), P(B), K(C)$ and $S(D)$ on watermelon crop cv. Magnum in relation to days after emergence (DAE) and their daily accumulation rates. Mossoró, UFERSA, 2015. 


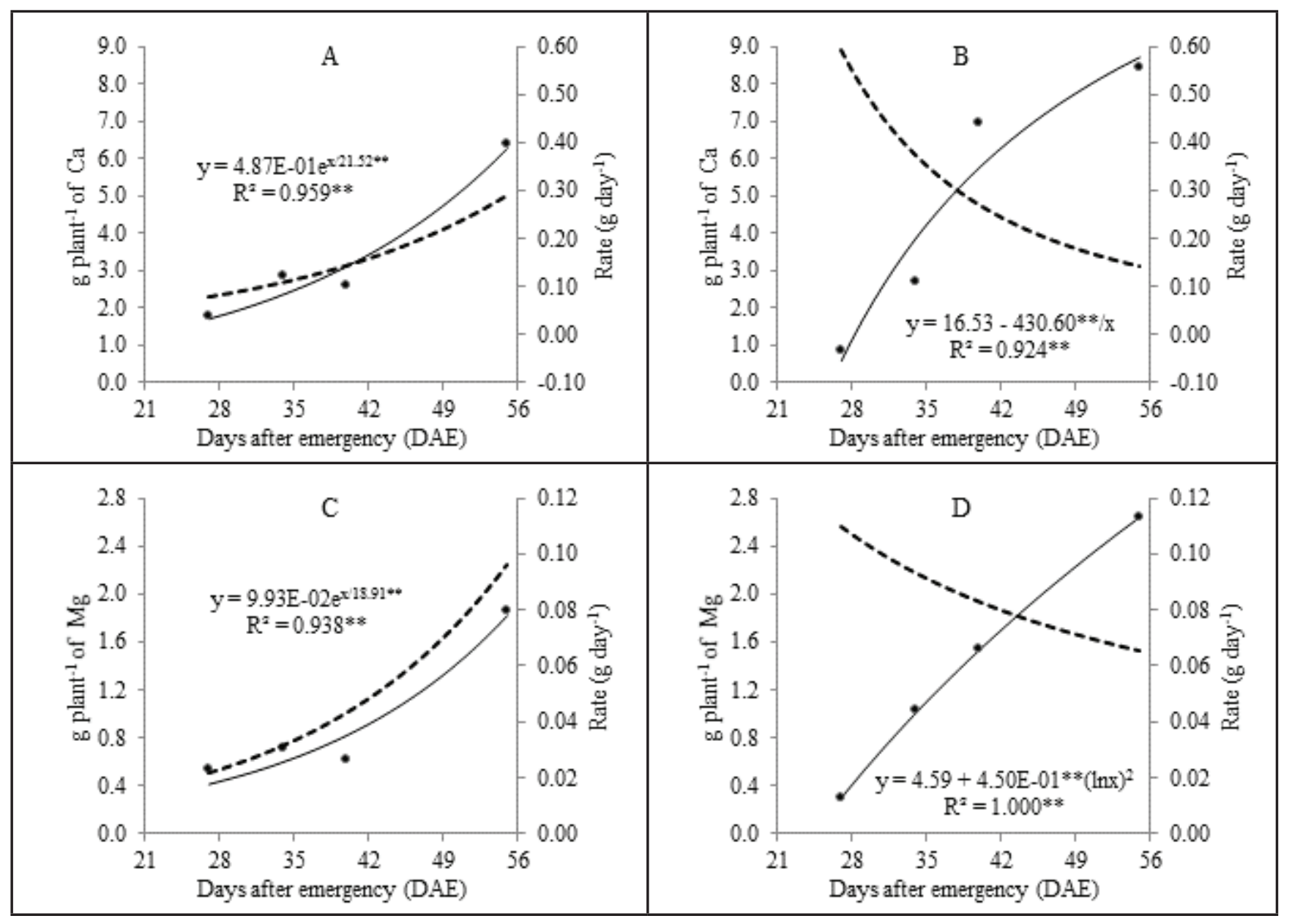

Figure 2. Total accumulations of $\mathrm{Ca}$ and $\mathrm{Mg}$ of watermelon cv. Magnum: $\mathrm{Ca}$ in F0 (A) and F1 (B) fertilizations and Mg in F0 (C) and F1 (D) fertilizations in relation to days after emergence (DAE) and respective daily accumulation rates. Mossoró, UFERSA, 2015.

vegetative part was explained due to a strong translocation of this nutrient to fruits.

At 55 DAE, plants accumulated an average of $1.42 \mathrm{~g}$ of $\mathrm{P}$ in their fruits (Figure 3B), significant differences between fertilization systems were noticed, though. Average accumulation in F1 fertilization during the cycle $(0.66$ $\mathrm{g}$ plant $\left.^{-1}\right)$ was significant superior $(\mathrm{p}=$ $0.01)$ comparing to $\mathrm{F} 0$ fertilization ( 0.43 $\mathrm{g}$ plant $\left.^{-1}\right)$, approximately $0.23 \mathrm{~g}$.

Based on the adjusted model for $\mathrm{P}$ in relation to DAE (Figure 3B) and on differences between fertilization systems, the authors estimated proportions of $\mathrm{P}$ exports in fruits of $84.1 \%$ and $83.1 \%$, respectively for F0 and $\mathrm{F} 1$ fertilizations. This result shows that an increase in $\mathrm{P}$ uptake practically does not change the nutrient partitioning pattern in plant.

This high proportion of $\mathrm{P}$ export corresponds to the one verified by Grangeiro \& Cecílio Filho (2004a), working with Tide hybrid (82\%). However, this behavior must also be related to balance of source-drain ratio in the plant.

Silva et al. (2012) and Vidigal et al. (2009) verified P export of $57 \%$ and $55 \%$ for cultivars Olímpia and Crimson Sweet, respectively. Some studies point out that movement and partitioning of $\mathrm{P}$ in the plant may not be a direct effect of its demand by the drains, but mainly a carbohydrate demand by the drains (Araújo \& Machado, 2006).

In relation to $\mathrm{K}$, the authors verified that, at the end of the experiment (55 DAE), about $13.95 \mathrm{~g}$ (Figure $3 \mathrm{C}$ ) or $77.4 \%$ of the maximum accumulated amount of $\mathrm{K}$ is allocated in fruits. Grangeiro \& Cecílio Filho (2004a) presented similar K export proportion for Tide hybrid (76\%).
Other studies show exports equivalent to $73 \%$ for Shadow hybrid (Grangeiro \& Cecilio Filho, 2005) and to $72 \%$ and $63.6 \%$ of the amount of $\mathrm{K}$ for cv. Leopard and cv. Olímpia, respectively (Silva et al., 2012).

Vidigal et al. (2009) stated that K in fruits corresponded to only $56 \%$ of the total in cv. Crimson Sweet. Some of these differences should be related to fruit partitioning, which in this study corresponded to approximately $70 \%$ of total biomass at the end of the cycle.

At the end of the experiment, $\mathrm{Ca}$ accumulated in fruits was of approximately $24.0 \%$ and $17.3 \%$ of the maximum accumulations in $\mathrm{F} 0$ and F1 fertilizations, respectively. This fact is due to the higher $\mathrm{Ca}$ accumulation in vegetative part, in F1 fertilization, noticed and that no differences for accumulation in fruits, $1.51 \mathrm{~g} \mathrm{plant}^{-1}$, at 55 DAE were verified (Figure 3D). 
According to Vitti et al. (2006), an increase in $\mathrm{Ca}$ concentration in the external solution may lead to an increase of accumulation in leaves, but not necessarily in fruits in relation to the mechanisms developed by plants to reduce the transport of this nutrient.

Reduction of $\mathrm{Ca}$ concentration in tissues is necessary for rapid cell expansion and membrane permeability (Marschner, 2012). Moreover, $\mathrm{Ca}$ is uptaken via transpiration, which leads an accumulation of this nutrient, mainly in the vegetative part (Marschner, 2012; Vidigal et al., 2009).

Final $\mathrm{Mg}$ accumulation in fruits is
$0.93 \mathrm{~g}$ (Figure 3E), corresponding to $51.35 \%$ and $35.40 \%$ of the respective nutrient total maximum in $\mathrm{F} 0$ and $\mathrm{F} 1$ fertilizations (Figures 2C and 2D), showing the relative mobility in the phloem when compared to $\mathrm{Ca}$.

Thus, as for $\mathrm{Ca}$, an increase of $\mathrm{Mg}$ uptake in plant does not mean higher

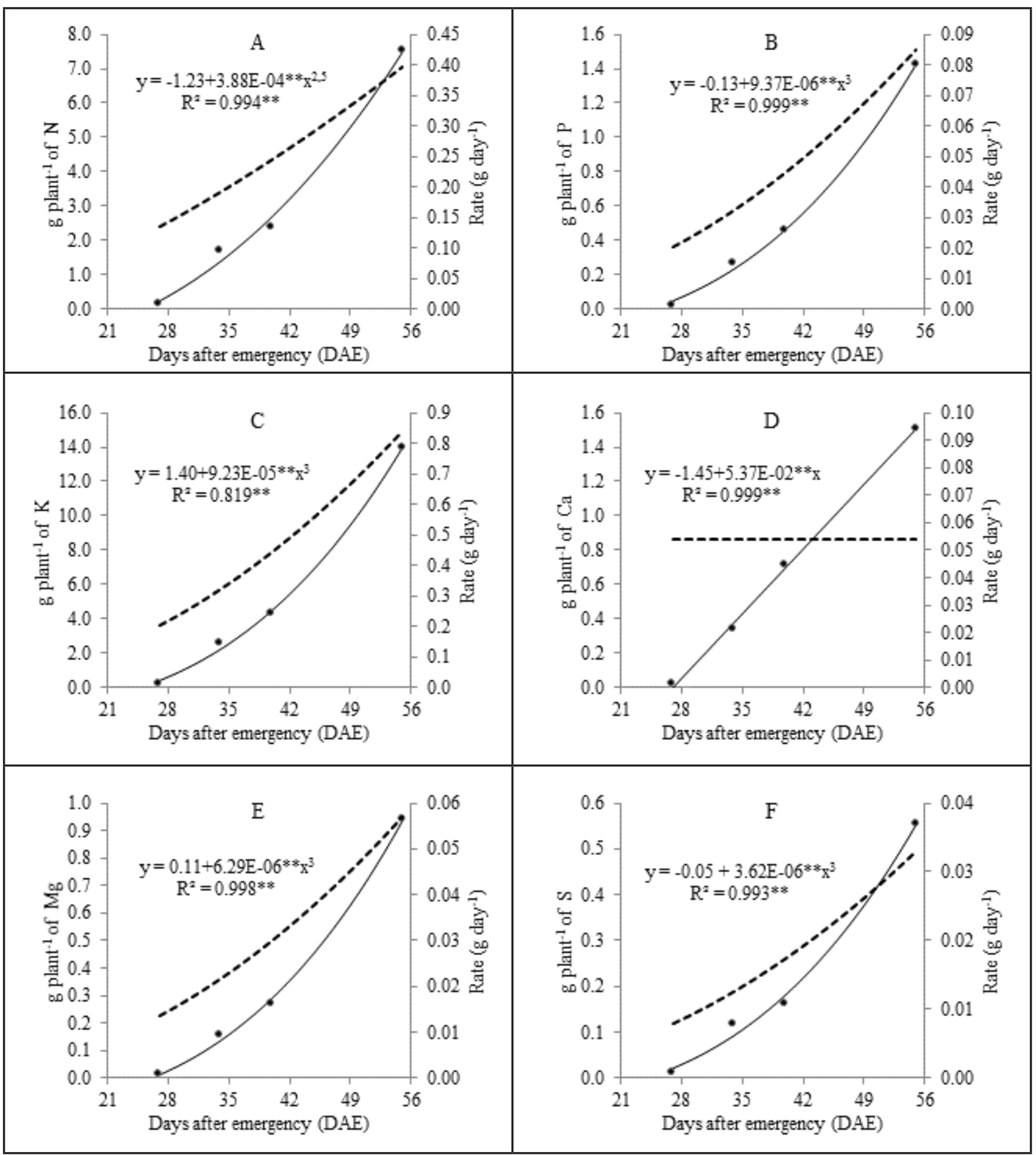

Figure 3. Accumulations of $\mathrm{N}(\mathrm{A}), \mathrm{P}(\mathrm{B}), \mathrm{K}(\mathrm{C}), \mathrm{Ca}(\mathrm{D}), \mathrm{Mg}(\mathrm{E})$ and $\mathrm{S}(\mathrm{F})$ in fruits of watermelon crop cv. Magnum in relation to days after emergence (DAE) and respective daily accumulation rates. Mossoró, UFERSA, 2015. 
exports of the nutrient in fruit. Marschner (2012) explains that continuous uptake and import via leaves after anthesis is one of the main causes of insufficiency of remobilization both of $\mathrm{Ca}$ and $\mathrm{Mg}$.

Silva et al. (2012) verified export proportion of $20 \% \mathrm{Ca}$ and $53 \% \mathrm{Mg}$ for cv. Olímpia and of $19 \% \mathrm{Ca}$ and $42 \% \mathrm{Mg}$ for cv. Leopard, in an experiment carried out in Baraúna, RN.

$\mathrm{S}$ is the nutrient with the lowest accumulation in fruits $\left(0.55 \mathrm{~g} \mathrm{plant}^{-1}\right)$; it corresponds to the highest part of what is accumulated in plant (61.38\%), though. Vidigal et al. (2009) and Grangeiro \& Cecílio Filho (2004a) also verified low $\mathrm{S}$ accumulation when comparing to other macronutrients in watermelon, exporting $52 \%$ and $65 \%$ of total accumulated for cv. Crimson Sweet and Tide hybrid, respectively.

Using the maximum values of the adjusted models, it is possible to establish the following order of nutrient accumulation in fruits in $\mathrm{F} 0$ fertilization: $\mathrm{K}>\mathrm{N}>\mathrm{Ca}>\mathrm{P}>\mathrm{Mg}>\mathrm{S}$ and in F1 fertilization: $\mathrm{K}>\mathrm{N}>\mathrm{P}>\mathrm{Ca}>\mathrm{Mg}>\mathrm{S}$ (Figure 3). Difference between fertilizations is due to higher $\mathrm{P}$ uptake in F1 fertilization, being also an indicative of $\mathrm{P}$ translocation capacity to fruits.

Considering planting density used $\left(8,333\right.$ plants $\left.\mathrm{ha}^{-1}\right)$, the authors are able to estimate that at the end of this experiment (55 DAE), the amounts exported of $\mathrm{N}, \mathrm{K}, \mathrm{Ca}, \mathrm{Mg}$ and $\mathrm{S}$ to fruits were $62.30,116.28,12.54,7.79$ and $4.60 \mathrm{~kg} \mathrm{ha}^{-1}$, respectively. For P in fruits, the authors estimated 10.93 and $12.81 \mathrm{~kg} \mathrm{ha}^{-1}$ in $\mathrm{F} 0$ and $\mathrm{F} 1$ fertilizations, respectively.

Overall, the highest macronutrient accumulations occurred in the last third of the crop cycle.

The general order of macronutrient accumulation was altered according to fertilization system used, considering an increase of $\mathrm{P}$ accumulation in $\mathrm{F} 1$ fertilization, both for the total and in fruits.

Range of macronutrient accumulation rates was increasing during evaluation, except for $\mathrm{Ca}$ and $\mathrm{Mg}$ in F1 fertilization.

F1 fertilization provided higher total accumulations of $\mathrm{Ca}$ and $\mathrm{Mg}$; the same did not occur for accumulation in fruits, though.

\section{ACKNOWLEDGEMENTS}

The authors are grateful to $\mathrm{CNPq}$ for financial support of this study.

\section{REFERENCES}

ARAÚJO, AP; MACHADO, CTT. 2006. Fósforo. In: FERNANDES, MS (ed). Nutrição mineral de plantas. Viçosa: SBCS, p.253-280.

CHIEN, SH; PORCHNOW, LI; TU, S; SNYDER, CS. 2011. Agronomic and enviromental aspects of phosphate fertilizers varying in source and solubility: an update review. Nutrient Cycling Agroecosystems 89: 229-255.

EMBRAPA - Embrapa Solos. 2009. Manual de análises químicas de solos, plantas $e$ fertilizantes. Brasília: Embrapa Informação Tecnológica. Brasília: Embrapa Solos. 627p.

FERNANDES, AM; SORATTO, RP. 2012. Nutrition, dry matter accumulation and partitioning and phosphorus use efficiency of potato grown at differente phosphorus levels in nutrient solution. Revista Brasileira de Ciência do Solo 36: 1528-1537.

FERREIRA, DF. 2010. Sistemas de análises de variância para dados balanceados: programa de análises estatísticas e planejamento de experimentos. SISVAR, v.4.

GONÇALVES, FCM; NASSER, MD; GOUVEIA, AMS; VILLAS BOAS, RL. 2016. Estudos da marcha de absorção de nutrientes para recomendação e adubação no cultivo da melancia. Revista Mirante 9: 46-58.

GRANJEIRO, LC; CECÍLIO FILHO, AB. 2004a. Acúmulo e exportação de macronutrientes pelo hibrido de melancia Tide. Horticultura Brasileira 22: 93-97.

GRANJEIRO, LC; CECÍLIO FILHO, AB. 2005. Acúmulo e exportação de nutrientes pela melancia sem sementes, híbrido Shadow. Cientifica 33: 69-74.

GRANGEIRO, LC; CECÍLIO FILHO, AB. 2004b. Exportação de nutrientes pelos frutos da melancia em função de épocas de cultivo, fontes de doses de potássio. Horticultura Brasileira 22: 740-743.
LUCENA, RRM; NEGREIROS, MZ; MEDEIROS, JF; GRANGEIRO, LC; MARROCOS, STP. 2011. Crescimento e acúmulo de macronutrientes em melancia 'Quetzale' cultivada sob diferentes níveis de salinidade da água de irrigação. Revista Caatinga 24: 34-42.

MALAVOLTA, E; VITTI, GC; OLIVEIRA, SA. 1997. Avaliação do estado nutricional das plantas: princípios e aplicações. Piracicaba: POTAFOS. 201p.

MAROUELLI, WA; GUIMARAES, TG; BRAGA, MB; CARVALHO, WL. 2015. Frações ótimas da adubação com fósforo no pré-plantio e na fertirrigação por gotejamento de tomateiro. Pesquisa Agropecuária Brasileira 50: 949-957.

MARSCHNER, H. 2012. Mineral nutrition of higher plants. 3.ed London: Elsevier. 634p.

NOVAIS, RF; MELLO, JWV. 2007. Relação solo-planta. In: NOVAIS, RF (ed). Fertilidade do solo. Viçosa: Sociedade Brasileira de Solos. p.133-204.

PAN, N; SHEN, H; WU, DM; DENG, LS; TU, PF; GAN, HH; LIANG, YC. 2011. Mechanism of improved phosphate uptake efficiency in banana seedlings on acidic soils using fertigation. Agricultural Water Management 98: 632-638.

PAULA, JAA; MEDEIROS, JF; MIRANDA, NO; OLIVEIRA, FA; LIMA, CJGS. 2011. Metodologia para determinação das necessidades nutricionais de melão e melancia. Revista Brasileira de Engenharia Agrícola e Ambiental 15: 911-916.

SCIENTIFIC, J. 1991. Table curve: curve fitting software. Corte Madera, 280p.

SILVA, MVT; CHAVES, SWP; MEDEIROS, JF; SOUZA, MS; SANTOS, APF; OLIVEIRA, FL. 2012. Acúmulo e exportação de macronutrientes em melancieiras fertirrigadas sob ótimas condições de adubação nitrogenada e fosfatada. CSA-Agropecuária Científica no Semi-Árido 8: 55-59.

TOMAZ, MA; SILVA, SR; SAKIYAMA, NS; MARTINEZ, HEP. 2003. Eficiência de absorção, translocação e uso de cálcio, magnésio e enxofre por mudas enxertadas de Coffea arabica. Revista Brasileira de Ciência do Solo 27: 885-892.

VIDIGAL, SM; PACHECO, DD; COSTA, EL; FACION, CE. 2009. Crescimento e acúmulo de macro e micronutrientes pela melancia em solo arenoso. Revista Ceres 56: 112-118.

VITTI, GC; LIMA, E; CICARONE, F. 2006. Cálcio, magnésio e enxofre. In: FERNANDES, MS (ed). Nutrição mineral de plantas. Viçosa: Sociedade Brasileira de Ciência do Solo. p.299-325.

WANG, J; CHU, G. 2015. Phosphate fertilizer form and application strategy affect phosphorus mobility and transformation in a drip-irrigated calcareous soil. Journal of Plant Nutrition and Soil Science, 178: 914-922. 